\title{
POTENSI KARANG LUNAK DI PERAIRAN DESA BUTON KABUPATEN MOROWALI
}

\section{Soft Coral Potential in Buton Village Waters, Morowali Regency}

\author{
Nurhayati $^{1}$, La Ode Muh. Yasir Haya ${ }^{2}$, Ratna Diyah Palupi ${ }^{3}$ \\ ${ }^{1}$ Mahasiswa Jurusan Ilmu Kelautan, \\ Fakultas Perikanan dan Ilmu Kelautan, Universitas Halu Oleo. \\ Jl. H.E.A Mokodompit Kampus Hijau Bumi Tridharma Anduonohu Kendari 93232, Telp/Fax: (0401) 3193782 \\ ${ }^{2}$ Surel: lmyasir.haya@gmail.com \\ ${ }^{3}$ Surel: pratna97@yahoo.com
}

\begin{abstract}
Abstrak
Karang lunak merupakan salah satu jenis biota laut yang menjanjikan di bidang farmakologis. Selain itu, bentuknya yang menarik dan warnanya yang indah dapat dijadikan sebagai karang hias aquarium. Penelitian ini bertujuan untuk mengetahui keanekaragaman, kepadatan, dan potensi karang lunak. Pengambilan data karang lunak dilakukan pada Bulan Maret 2019 di Perairan Desa Buton. Metode pengambilan data karang lunak dilakukan pada 3 stasiun yang berlokasi di zona reef flat dan reef slope. Data karang lunak diperoleh dengan metode belt transect dengan luas area pengamatan 120 $\mathrm{m}^{2}$. Potensi karang lunak dianalisis secara deskriptif dengan mencocokkan jenis soft coral yang ditemukan dengan hasil penelitian yang pernah dilakukan. Hasil penelitian menunjukkan bahwa keanekaragaman karang lunak yang ditemukan terdiri dari 6 famili, 10 genera, 14 jenis, dan 192 individu. Genera yang dominan ditemukan meliputi Sarcophyton, Sinularia, Isis, dan Klyxum. Kepadatan karang lunak yang diperoleh berkisar 0,342-0,683 ind./ $/ \mathrm{m}^{2}$ dengan kepadatan tertinggi terdapat di zona reef slope Semua jenis karang lunak yang ditemukan di lokasi penelitian berpotensi di bidang farmakologis dan karang hias. Potensi terbesar adalah sebagai anti tumor, anti bakteri, dan karang hias aquarium. Diperlukan penelitian lebih lanjut potensi karang lunak khususnya dari aspek mikrobiologi untuk melihat senyawa bioaktifnya.
\end{abstract}

Kata Kunci: karang lunak, keanekaragaman, kepadatan, potensi, Perairan Desa Buton

\begin{abstract}
Soft coral is atype of marinebiota in the pharmacological field. Besides, the attractive shape and beautiful color could be used as ornamental aquarium corals. This study aims to determine the diversity, density, and potential of soft corals. Primary data was collected in March 2019 at the waters of Buton Village, which conducted at three stations located in the reef flat and reef slope zones. Soft coral data obtained by the belt transect method with an area of observation area of 120 $\mathrm{m}^{2}$. The potential of soft corals was analyzed descriptively by matching the types of soft corals found with the results of previous studies. The results showed that the diversity of soft corals found consisted of 6 families, ten genera, 14 species, and 192 individuals. The dominant genera found include Sarcophyton, Sinularia, Isis, and Klyxum. The density of soft corals obtained ranged from 0.342 to 0.683 ind.$/ \mathrm{m}^{2}$ with the highest density found in the reef slope zone. All types of soft corals found at the study site have the potential in the field of pharmacological and ornamental corals. The most significant potential is as an anti-tumor, anti-bacterial, and aquarium ornamental corals. Further research is needed on the potential of soft corals, particularly from microbiological aspects, to look at their bioactive compounds.
\end{abstract}

Keywords: soft coral, diversity, density, potential, waters of buton village

\section{Pendahuluan}

Ekosistem terumbu karang merupakan salah satu ekosistem wilayah pesisir yang mempunyai peranan sangat penting baik dari aspek ekologis maupun ekonomi. Secara ekologis, ekosistem terumbu karang merupakan tempat berbagai organisme yang berasosiasi dengannya untuk berlindung, mencari makan dan berkembang biak. Disamping itu, secara ekonomi, ekosistem terumbu karang memiliki nilai ekonomi sebagai penyedia barang dan jasa diantaranya sebagai perikanan tangkap, pariwisata, serta merupakan daerah "fishing ground" yang potensial terutama bagi nelayan tradisional (Haya and Fuji, 2019).

Keberadaan terumbu karang ini masih perlu dilakukan pemanfaatannya selain dari salah satu tempat wisata. Ekosistem terumbu karang terdiri dari dua jenis yaitu karang keras dan karang lunak. Karang lunak mampu bersimbion dengan mikroorganisme seperti jamur. Jamur yang bersimbion berasal dari laut merupakan mikroba yang kaya akan produk alami bioaktif dan metabolit sekunder, 
yang dapat membantu pertahanan diri dari lingkungannya (Putri $d k k$., 2019)

Karang lunak merupakan sumber yang kaya akan senyawa bioaktif seperti terpenoid, steroid glikosida, alkaloid, flafonoid, fenol, saponin, dan peptide. Hasil penelitian menyebutkan bahwa sekitar 50\% ekstrak karang lunak menunjukkan sifat racun pada ikan, selain itu banyak metabolit sekunder yang dihasilkan oleh karang lunak memiliki aktivitas biologi, seperti anti fungi, sintisik, anti neoplastik, anti mikroba, inhibitor HIV dan anti inflamantori (Radhika, 2006).

Sebagai contoh Sarcophyton sp. dan Sinularia sp. merupakan salah satu jenis karang lunak yang memproduksi senyawa kimia alami dan dikenal dengan istilah natural product. Senyawa kimia alami tersebut berpotensi sebagai sumber obat alami. Hasil penelitian yang dilakukan Apri, $d k k$. (2017) dan Galih, $d k k$. (2019) menunjukkan bahwa senyawa kimia aktif yang terdapat pada karang lunak Sarcophyton sp. menunjukkan aktivitas sebagai antibakteri, antifungi, antitumor, neurotoksik, dan antiinflamantori yang bermanfaat bagi industri farmasi.

Besarnya potensi senyawa bioaktif yang terdapat pada karang lunak tersebut menjadi perhatian besar bagi para peneliti. Ekstrak metabolit dari karang lunak dipercaya mengandung senyawa bioaktif yang mempunyai sifat sitotoksin, anti tumor, anti virus, anti inflamasi, anti jamur dan lainnya. Selain sebagai sumber senyawa bahan alam, karang lunak juga memiliki manfaat yang lain, yakni digunakan sebagai hewan bernilai ekonomis untuk hiasan akuarium (Hanum and Aditya, 2013).
Perairan Desa Buton merupakan perairan yang terletak di Kecamatan Bungku Selatan, Kabupaten Morowali, Sulawesi Tengah. Berdasarkan survey pendahuluan yang telah dilakukan, perairan tersebut memiliki keanekaragaman hayati laut seperti terumbu karang yang sangat potensial untuk dikembangkan, dimana perairannya masih tergolong alami dan jernih serta terumbu karangnya yang masih cukup berlimpah khususnya karang lunak. Akan tetapi habitat hidup karang lunak pada perairan ini terlihat terus mengalami degradasi sehingga dikhawatirkan mengancam kelestarian biota laut di dalamnya. Berbagai macam sumber kerusakan baik karena alam maupun antropogenik dapat mengancam kelestarian karang lunak. Akan tetapi kerusakan terbesar adalah karena ulah manusia. Penelitian ini bertujuan untuk mengetahui keanekaragaman, kepadatan dan potensi karang lunak di Perairan Desa Buton Kabupaten Morowali. Penelitian ini bertujuan untuk mengetahui keanekaragaman, kepadatan, dan potensi karang lunak.

\section{Bahan dan Metode}

Penelitian ini berlangsung selama sepuluh bulan mulai dari Januari sampai Okober 2019. Meliputi tahap persiapan, pengambilan data lapangan, pengolahan data, analisis data, sampai pembuatan laporan akhir. Pengambilan data dilaksanakan pada bulan Maret 2019 bertempat di Perairan Desa Buton, Kabupaten Morowali, Sulawesi Tengah.

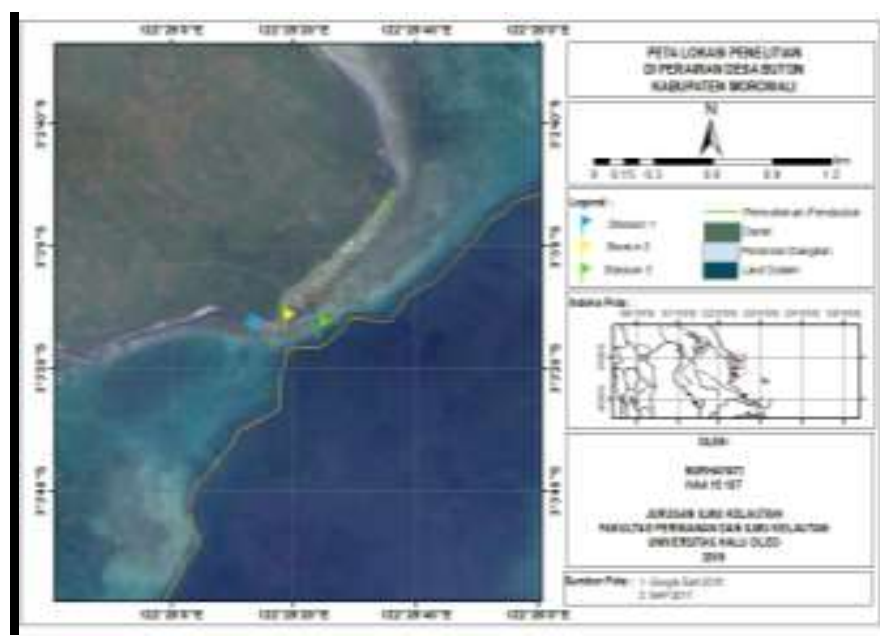

Gambar 1. Peta Lokasi Penelitian 
Tabel 1. Lokasi pengambilan data dan titik koordinat

\begin{tabular}{|c|c|c|}
\hline Lokasi Sampling & Koordinat & Keterangan \\
\hline Stasiun 1 & $\begin{array}{r}03^{\circ} 3^{\prime} 37.31^{\prime \prime} \mathrm{LS} \\
122^{\circ} 25^{\prime} 10.71^{\prime \prime} \mathrm{BT}\end{array}$ & $\begin{array}{l}\text { Substrat pasir, karang mati, dan } \\
\text { sedikit patahan karang. }\end{array}$ \\
\hline Stasiun 2 & $\begin{array}{r}03^{\circ} 3^{\prime} 37.86^{\prime \prime} \mathrm{LS} \\
122^{\circ} 25^{\prime} 15.58^{\prime} \mathrm{BT}\end{array}$ & $\begin{array}{l}\text { Substrat berpasir dan didominasi oleh } \\
\text { patahan karang }\end{array}$ \\
\hline Stasiun 3 & $\begin{array}{r}03^{\circ} 3^{\prime} 37.77^{\prime \prime} \mathrm{LS} \\
122^{\circ} 25^{\prime} 21.63^{\prime \prime} \mathrm{BT}\end{array}$ & $\begin{array}{l}\text { Substrat didominasi patahan karang } \\
\text { dan sedikit pasir serta banyak karang } \\
\text { mati yang ditutupi alga (DCA). }\end{array}$ \\
\hline
\end{tabular}

Pengambilan data dilakukan dengan menggunakan metode transek sabuk (belt transect). Tiap titik stasiun penelitian, dilakukan penarikan garis dengan meteran roll sejajar garis pantai dengan panjang garis transek $30 \mathrm{~m}$ dengan lebar observasi $2 \mathrm{~m}$ kiri dan $2 \mathrm{~m}$ kanan sehingga luas pemantauan menjadi $120 \mathrm{~m}^{2}$. Selanjutnya, pada tiap titik stasiun dilakukan pengulangan sebanyak dua kali pengulangan dengan jarak $10 \mathrm{~m}$. Pengambilan data karang lunak dilakukan pada kedalaman 3 dan $7 \mathrm{~m}$ yang mewakili zona reef flat dan reef slope. Pengambilan data keanekaragaman dilakukan dengan melihat tiap jenis karang lunak. Sedangkan, identifikasi data kepadatan dilakukan dengan menghitung tiap jenis karang lunak yang ditemukan. Pengambilan data dilakukan dengan menggunakan bantuan alat scuba. Identifikasi karang lunak dilakukan dengan pengambilan gambar menggunakan kamera underwater. Proses identifikasi dibantu dengan menggunakan buku identifikasi Yehuda $d k k$., (2004) dan Manuputty (2002).

Pengukuran parameter kimia fisika oseanografi dilakukan secara in situ yang bertujuan untuk mengetahui kondisi perairan tersebut. Pengukuran parameter kimia fisika oseanografi meliputi pengukuran suhu, salinitas, kecepatan arus, $\mathrm{pH}$, kecerahan, dan kedalaman.

Keanekaragaman hayati karang lunak dilihat secara visual berdasarkan ciri-ciri morfologi dan panduan taksonomi. Data hasil pengamatan selanjutnya diketahui berdasarkan jumlah jenis karang lunak yang ditemukan pada lokasi penelitian.

Kepadatan jenis karang lunak dianalisis dengan menggunakan rumus kepadatan (Krebs, 1999):

$D=\frac{\mathrm{ni}}{\mathrm{A}}$
Keterangan:

$\mathrm{D}=$ Kepadatan jenis karang lunak (ind. $/ \mathrm{m}^{2}$ )

ni $=$ Jumlah koloni karang lunak jenis ke-i ditiap stasiun (ind)

$\mathrm{A}=$ Luas daerah penelitian $\left(\mathrm{m}^{2}\right)$

Analisis pontensi karang lunak dilakukan secara deskriptif yang bersumber dari data sekunder berdasarkan studi literatur yang ada.

\section{Hasil dan Pembahasan}

Keanekaragaman karang lunak yang ditemukan di lokasi penelitian yaitu terdapat 6 famili, 10 genera, 14 jenis dan 192 individu karang lunak, dengan keanekarangaman tertinggi terdapat di daerah reef slope. Berdasarkan stasiun keanekaragaman tertinggi terdapat pada stasiun I dan keanekaragaman terendah terdapat pada stasiun III.

Keanekaragaman tertinggi di Perairan Desa Buton yaitu terdapat pada stasiun I. Keanekaragaman karang lunak di daerah ini cukup tinggi diduga karena dipengaruhi oleh faktor fisika kimia perairan yang masih tergolong baik. Misalnya, kecepatan arus, dimana kecepatan arus sangat berpengaruh terhadap pertumbuhan karang lunak. Kecepatan arus yang ditemukan pada stasiun I cukup kuat yaitu $0,11 \mathrm{~m} / \mathrm{s}$ dibandingkan pada stasiun II dan III yaitu berkisar 0,09 dan 0,07 $\mathrm{m} / \mathrm{s}$. Arus berfungsi sebagai media transporter zat makanan dan suplai oksigen ke tubuh biota serta dapat membersihkan koloni karang lunak dari partikel-partikel pengganggu seperti sedimen. Hal ini sesuai dengan pernyataan Sugiyanto (2004) yang menyatakan bahwa kecepatan arus memperoleh sumber air yang segar, memberi oksigen, menghalangi pengendapan sedimen, sumber nutrien dan makanan. 
Tabel 2. Keanekaragaman karang lunak yang ditemukan di daerah reefflat $(3 \mathrm{~m})$

\begin{tabular}{|c|c|c|c|c|c|}
\hline \multirow[t]{2}{*}{ Famili } & \multirow[t]{2}{*}{ Genera } & \multirow[t]{2}{*}{ Jenis Karang Lunak } & \multicolumn{3}{|c|}{$\begin{array}{c}\text { Jumlah Individu } \\
\text { Karang Lunak }\end{array}$} \\
\hline & & & ST I & ST II & ST III \\
\hline \multirow[t]{7}{*}{ Alcyoniidae } & Sarcophyton & Sarcophyton sp. & 2 & - & 2 \\
\hline & & Sarcopyton ehrenbergi & 5 & - & 6 \\
\hline & & Sarcophyton glaucum & - & 6 & - \\
\hline & Sinularia & Sinularia flexibilis & 6 & - & - \\
\hline & & Sinularia polydactyla & 4 & 4 & - \\
\hline & Klyxum & Klyxum sp. & - & 10 & - \\
\hline & Lobophytum & Lobophytum pauciflorum & - & 4 & - \\
\hline \multirow[t]{2}{*}{ Nephtheidae } & Lemnalia & Lemnalia flava & 3 & - & 2 \\
\hline & Capnella & Capnella sp. & 3 & - & 3 \\
\hline Isididae & Isis & Isis hippuris & - & 7 & - \\
\hline Total: 3 & 7 & 10 & 23 & 29 & 13 \\
\hline \multicolumn{3}{|c|}{ Jumlah jenis } & 6 & 5 & 4 \\
\hline
\end{tabular}

Tabel 3. Keanekaragaman karang lunak yang ditemukan di daerah reef slope $(7 \mathrm{~m})$

\begin{tabular}{|c|c|c|c|c|c|}
\hline \multirow{2}{*}{ Famili } & \multirow{2}{*}{ Genera } & \multirow{2}{*}{ Jenis Karang Lunak } & \multicolumn{3}{|c|}{$\begin{array}{c}\text { Jumlah Individu } \\
\text { Karang Lunak }\end{array}$} \\
\hline & & & ST I & ST II & ST III \\
\hline \multirow[t]{5}{*}{ Alcyoniidae } & Sarcophyton & Sarcophyton sp. & 61 & 12 & - \\
\hline & & Sarcopyton ehrenbergi & 5 & 4 & 3 \\
\hline & Klyxum & Klyxum sp. & 2 & 3 & - \\
\hline & Lobophytum & Lobophytum pauciflorum & - & 1 & - \\
\hline & & Lobophytum strictum & 2 & 1 & - \\
\hline Nephtheidae & Capnella & Capnella sp. & - & - & 1 \\
\hline Isididae & Isis & Isis hippuris & - & 15 & 10 \\
\hline Gorgoniidae & Gorgonia & Gorgonia sp & 1 & - & 1 \\
\hline Xeniidae & Xenia & Xenia sp. & 2 & - & 1 \\
\hline Clavulariidae & Clavularia & Clavularia sp & 1 & - & - \\
\hline Total : 6 & 8 & 10 & 74 & 37 & 16 \\
\hline \multicolumn{3}{|c|}{ Jumlah jenis } & 7 & 6 & 5 \\
\hline
\end{tabular}

Keanekaragaman karang lunak terendah terdapat pada stasiun III (Tabel 2 dan 3). Daerah ini dekat dengan pemukiman warga dan berhadapan langsung dengan dermaga. Rendahnya keanekaragaman karang lunak di daerah ini disebabkan kondisi lingkungan yang tidak mendukung seperti aktivitas manusia yang tidak ramah lingkungan (pembuangan minyak kapal) yang menyebabkan kondisi karang di daerah ini banyak yang rusak. Selanjutnya, banyaknya alga yang tumbuh di daerah ini juga berpengaruh terhadap pertumbuhan karang lunak karena larva karang lunak kebanyakan menempel pada substrat yang keras seperti karang mati. Selain itu, laju kecepatan arusnya rendah yaitu berkisar $0,07 \mathrm{~m} / \mathrm{s}$. Nybakken (1992) menyatakan bahwa kecepatan arus sangat berpengaruh terhadap pertumbuhan karang lunak. Penelitain yang dilakukan di Pulau Cemara Kecil Kepulauan Karimun Jawa (Nababan, dkk., 2015) diperoleh hasil keanekaragaman karang lunak yang ditemukan sebanyak 4 jenis untuk di daerah rataan dan tubir dengan kondisi substrat karang hidup, pecahan karang, karang mati, dan pasir.

Berdasarkan hasil penelitian, kepadatan karang lunak tertinggi terdapat di daerah reef slope pada stasiun I. Kepadatan terendah terdapat di daerah reef flat yaitu pada stasiun III. Sedangkan berdasarkan jenis kepadatan tertinggi yaitu karang lunak jenis Sarcophyton sp. daerah reef slope pada stasiun I.

Berdasarkan stasiun kepadatan karang lunak tertinggi yaitu terdapat pada stasiun I . Hal ini dipengaruhi oleh faktor kondisi kualitas perairan, kualitas perairan pada stasiun I merupakan kondisi yang sesuai untuk kehidupan karang lunak. 
Fabricius and Alderslade (2001), menyatakan bahwa kepadatan karang lunak juga sangat dipengaruhi oleh kondisi parameter perairan pada suatu perairan. kecepatan arus pada I cukup kuat dibandingkan pada stasiun II dan III. nilai kecepatan arus yang di dapat pada stasiun I yaitu sebesar $0,11 \mathrm{~m} / \mathrm{s}$. Hal ini sesuai dengan penyataan Sugiyanto (2004) yang menyatakan bahwa kecepatan arus memperoleh sumber air yang segar, memberi oksigen, menghalangi pengendapan sedimen, sumber nutrien dan makanan. Selain kecepatan arus ada faktor lain yang mempengaruhi yaitu seperti kondisi substrat dimana karang lunak menyukai substrat yang keras untuk tempat pertumbuhan larva. Hal ini sesuai dengan pernyataan Munasik (2009) bahwa substrat dasar yang keras dan kompak deperlukan pada pertumbuhan karang terutama sebagai tempat menempelnya larva karang (planula).

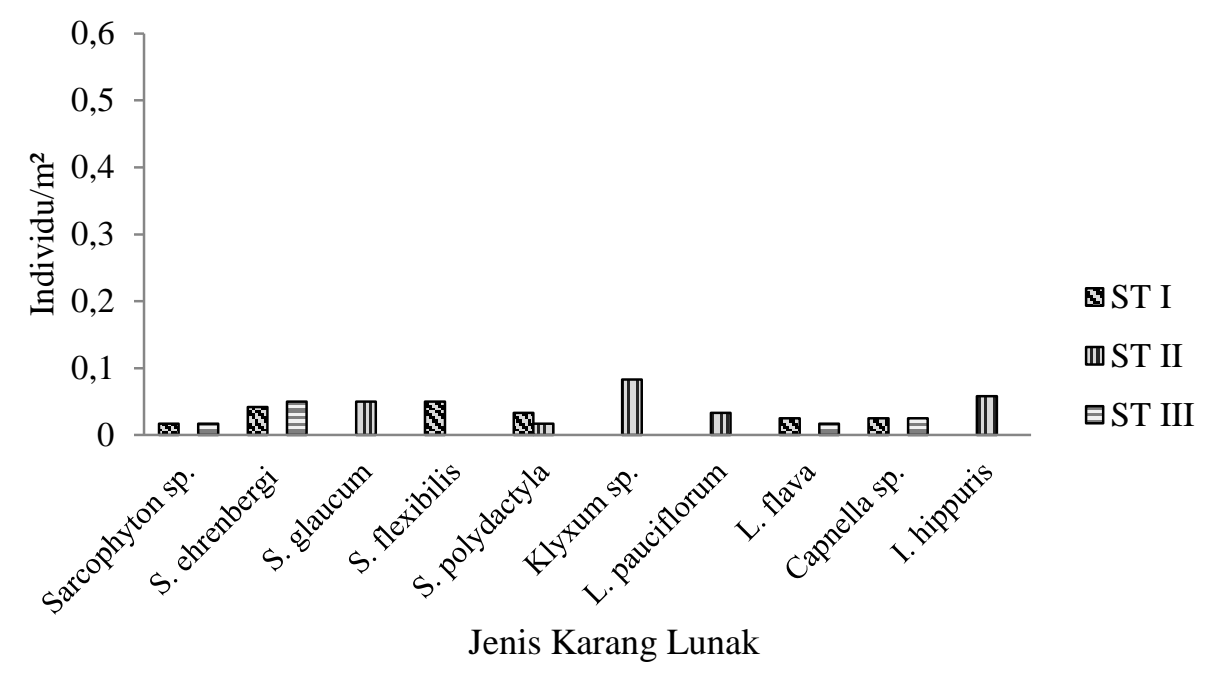

Gambar 2. Grafik Kepadatan karang lunak yang ditemukan di daerah reefflat di perairan Desa Buton, Kabupaten Morowali.

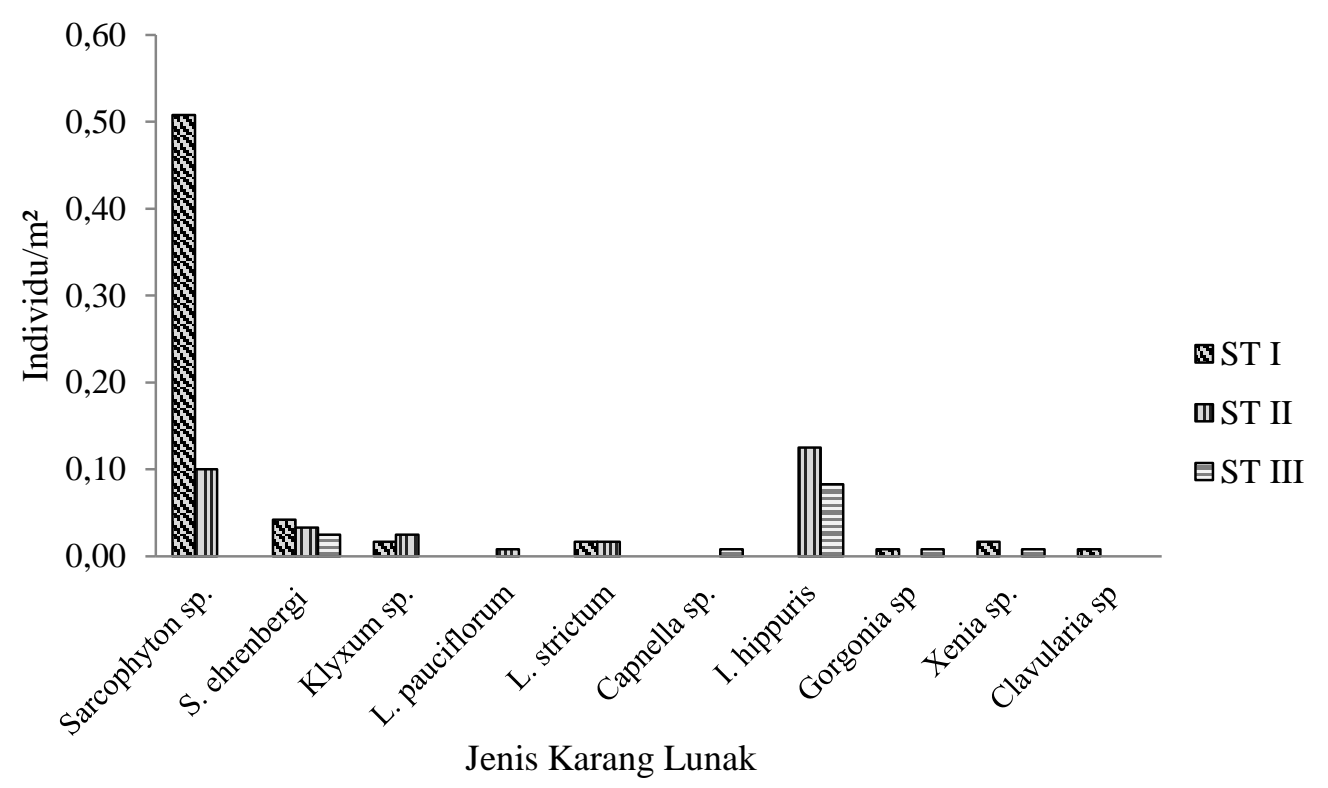

Gambar 3. Grafik Kepadatan karang lunak yang ditemukan di daerah reef slope di perairan Desa Buton, Kabupaten Morowali. 
Tabel 4. Parameter kimia fisika oseanografi di Perairan Desa Buton.

\begin{tabular}{lccc}
\hline Parameter Perairan & Stasiun I & Stasiun II & Stasin III \\
\hline Kecepatan arus $(\mathrm{m} / \mathrm{s})$ & 0,11 & 0,09 & 0,07 \\
Kecerahan $(\%)$ & 100 & 100 & 100 \\
Salinitas $(\mathrm{ppt})$ & 35 & 35 & 35 \\
$\mathrm{Ph}$ & 7 & 7 & 8 \\
Suhu $\left({ }^{\circ} \mathrm{C}\right)$ & 32 & 32 & 31 \\
\hline
\end{tabular}

Kepadatan karang lunak terendah terdapat pada stasiun III yaitu di daerah reef flat dengan nilai kepadatan 0,108 ind. $/ \mathrm{m}^{2}$ dimana Sarcopyton ehrenbergi merupakan jenis koloni karang lunak yang mendominasi kepadatan di perairan tersebut dengan nilai kepadatan 0,050 ind. $/ \mathrm{m}^{2}$ (Gambar 2). Hal ini disebabkan pada stasiun III merupakan daerah yang dekat dengan dermaga dan sering terjadi aktivitas manusia yang tidak ramah lingkungan. Selai itu, banyaknya alga yang tumbuh di daerah ini menyebabkan karang lunak tidak dapat tumbuh karena kondisi ruang yang tidak mencukupi. Stasiun III merupakan daerah yang memiliki kecepatan arus terendah dari semua stasiun. Kecepatan arus pada stasiun III yaitu $0,7 \mathrm{~m} / \mathrm{s}$. Menurut Wikanta $d k k$., (2006), arus diperlukan karang untuk memperoleh makanan berupa zooplankton, oksigen dan mencegah tutupan sedimentasi yang berlebihan.

Berdasarkan zona terumbu karang kepadatan jenis karang lunak tertinggi terdapat di daerah reef slope di bandingkan di daerah reef flat. Hal ini karena dipengaruhi aktifitas pasang surut pada daerah rataan (reef flat) dimana karang lunak tidak dapat bertahan hidup pada kondisi perairan yang salinitasnya tinggi dan berubah-ubah. Selain itu, karang lunak selalu melipah pada karang mati dan batuan dasar. Substrat merupakan faktor yang sangat penting untuk menentukan penyebaran karang lunak (Arafat, 209). Selain itu, faktor fisika dan kimia juga sangat berpengaruh terhadap kepadatan karang lunak. Fikri $d k k$, (2013) menyatakan bahwa, perbedaan kepadatan di setiap zonasi dipengaruhi oleh faktor kondisi oseanografi di dua zona yang berbeda. Dimana pada zona reef flat dalam kondisi tertentu yaitu faktor cahaya, naik turunnya pasang surut, sedimentasi yang tinggi, rendahnya salinitas serta arus yang kuat, biota tersebut kurang mampu untuk bertoleransi terutama bila waktunya lama. Hanya beberapa jenis yang bisa bertahan dalam kondisi tersebut (kekeringan dan sebagainya). Hewan ini sering menyebar pada kedalaman dibawah surut terendah menghindari proses pengeringan (Fabricius and De'ath 2000). Jenis karang lunak yang nilai kepadatannya tinggi, yaitu koloni Sarcophyton sp. pada stasiun I di daerah reef slope dengan nilai kepadatan $1,017 \mathrm{ind} . / \mathrm{m}^{2}$ (Gambar 3). Kehidupan karang lunak juga tergantung pada kondisi lingkungan di sekitar tempat tumbuhnya, terutama substrat dasar yang keras untuk perlekatan larva. Parameter perairan yang mempengaruhi adalah parameter fisika, seperti cahaya matahari, pasang surut dan sedimentasi. Tingkat toleransi dan adaptasi karang lunak terhadap faktor-faktor lingkungan tersebut berbeda pada masing-masing individu, jenis maupun marga (Manuputty, 2008). Jenis karang Sarcophyton sering menyebar pada kedalaman di bawah surut terendah menghindari proses pengeringan (Arafat, 2009).

Berdasarkan hasil identifikasi dan studi literatur menunjukkan bahwa karang lunak yang di temukan pada lokasi penelitian terdapat 7 jenis yang berpotensi sebagai anti tumor, 4 jenis anti bakteri, 1 jenis anti kanker, 1 jenis antioksidan, 1 jenis antibiotik, dan 5 jenis berpotensi sebagai karang hias.

Potensi karang lunak terbesar untuk dikembangkan adalah jenis Sarcophyton sp. dengan kepadatan sebesar 1,017 ind. $/ \mathrm{m}^{2}$. Jenis karang lunak ini berpotensi sebagai karang hias aquarium dan digunakan di bidang industri farmakologi sebagai bahan obatobatan yaitu sebagai obat anti bakteri. Berdasarkan hasi penelitian dari Tinambunan, (2012) menyatakan bahwa, Sarcophyton sp. efektif menghambat pertumbuhan bakteri Escherichia coli (bakteri dalam pencernaan) dan Staphylococcus aureus karena memiliki daerah hambatan dalam kategori kuat. Karang lunak sarcophyton sp. masih ditemukan melimpah. Hal ini juga disebabkan masyarakat di Desa ini belum mengetahui bahwa karang lunak jenis sarcophyton $\mathrm{sp}$ berpotensi dalam bidang farmakologi. 
Tabel 5. Potensi Karang Lunak di Perairan Desa Buton.

\begin{tabular}{ccl}
\hline No. & Jenis Karang Lunak & \multicolumn{1}{c}{ Potensi } \\
\hline $1 . \quad$ & Klyxum sp. & \\
& &
\end{tabular}

\section{Xenia sp.}

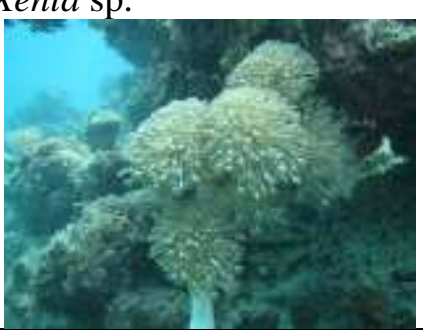

Karang ini ditemukan pada zona reef slope $(7 \mathrm{~m})$. Melekatkan diri atau hidup pada karang mati

Berpotensi sebagai :

- Anti tumor (Novilia $d k k ., 2015)$

- Anti bakteri (Novilia $d k k ., 2015)$

- Karang hias aquarium (Moelyono, 2016)

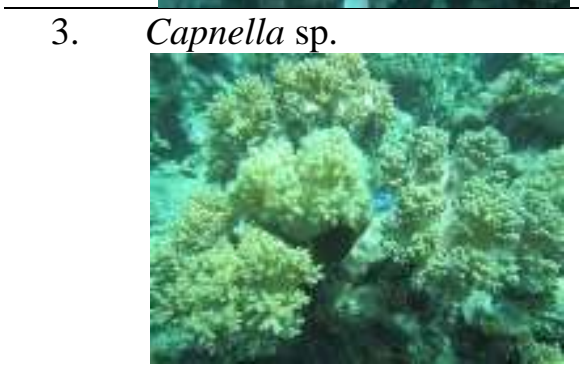

Karang ini ditemukan pada zona reef flat $(3 \mathrm{~m})$ dan reef slope $(7 \mathrm{~m})$. Melekatkan diri atau hidup pada karang mati Berpotensi sebagai :

- Anti tumor (Werorilangi dan Abdul, 2010

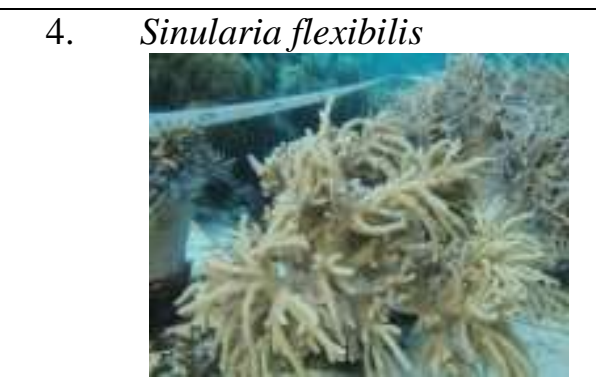

Karang ini ditemukan pada zona reef flat $(3 \mathrm{~m})$. Hidup pada substrat berpasir dan karang mati.

Berpotensi sebagai :

- Anti bakteri (Rozirwan $d k k ., 2015)$

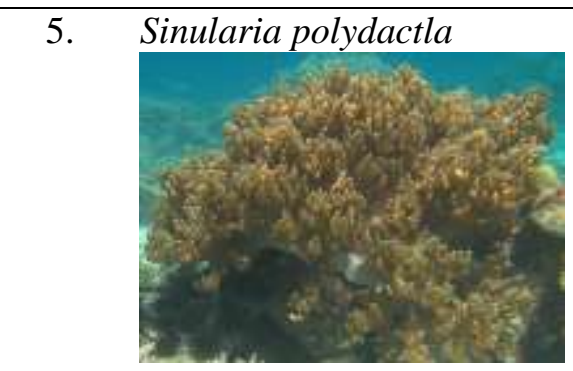

Karang ini ditemukan pada zona reef flat $(3 \mathrm{~m})$. Hidup pada substrat berpasir dan karang mati.

Berpotensi sebagai :

- Antibiotik (Putri, $d k k ., 2019)$

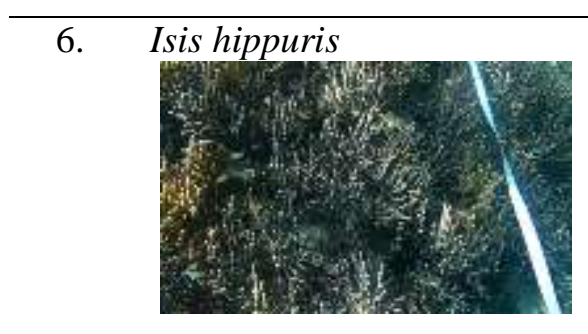

Karang ini ditemukan pada zona reef flat $(3 \mathrm{~m})$ dan reef slope $(7 \mathrm{~m})$. Hidup pada substrat berpasir dan karang mati.

Berpotensi sebagai :

- Bahan Keramik (Bahri, 2016)

- Anti kanker

- Anti Virus (Manuputty, 2008) 


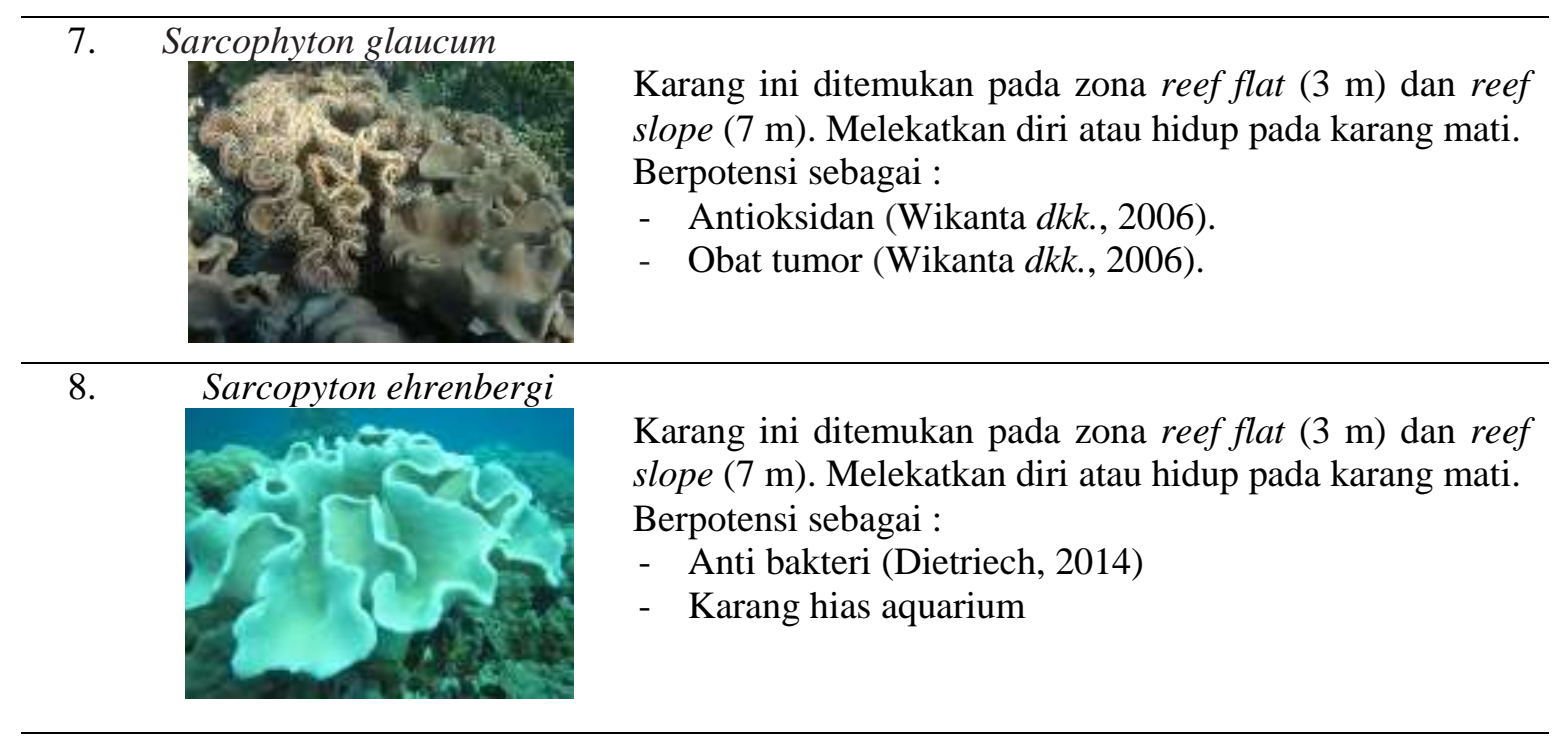

9. Sarcophyton

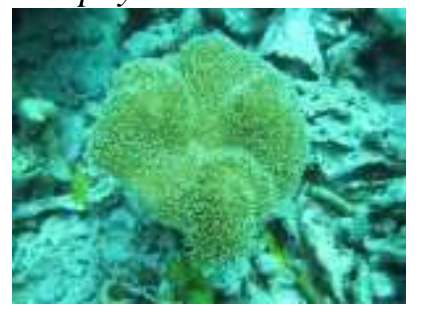

10. Gorgonian

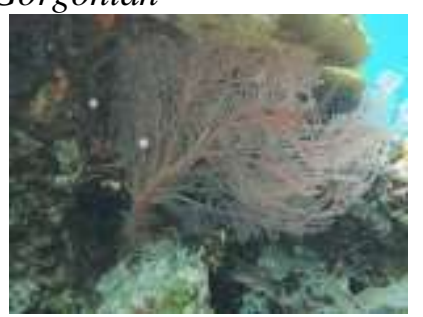

11. Lemnalia flava

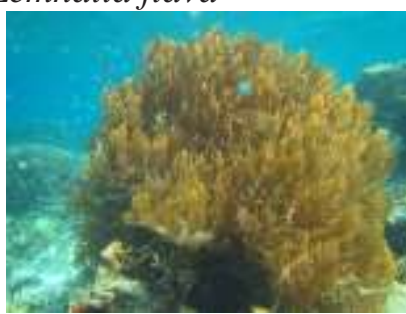

Karang ini ditemukan pada zona reef flat $(3 \mathrm{~m})$. Menyukai substrat yang keras seperti karang mati dan pasir.

Berpotensi sebagai :

- Karang hias aquarium

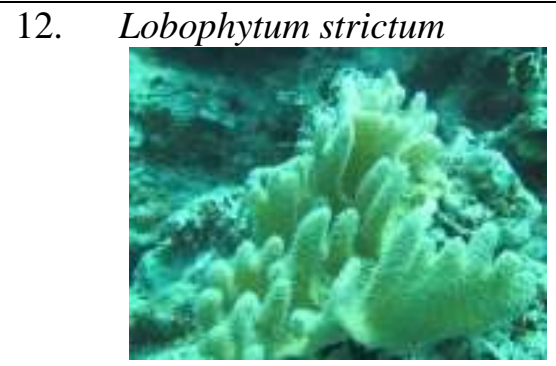

Karang ini ditemukan pada zona reef flat $(3 \mathrm{~m})$ dan reef slope $(7 \mathrm{~m})$. Melekatkan diri atau hidup pada karang mati. Berpotensi sebagai :

- Anti tumor (Iswani, dkk., 2014).

Karang ini ditemukan pada zona reef flat $(7 \mathrm{~m})$. Hidup di sela-sela karang dan di bagian lereng terumbu.

Berpotensi sebagai :

- Karang hias aquarium (Moelyono, 2016)

Karang ini ditemukan pada zona reef slope $(7 \mathrm{~m})$. Melekatkan diri atau hidup pada karang mati.

Berpotensi sebagai :

- Anti tumor (Werorilangi dan Abdul, 2010)

- Karang hias aquarium 


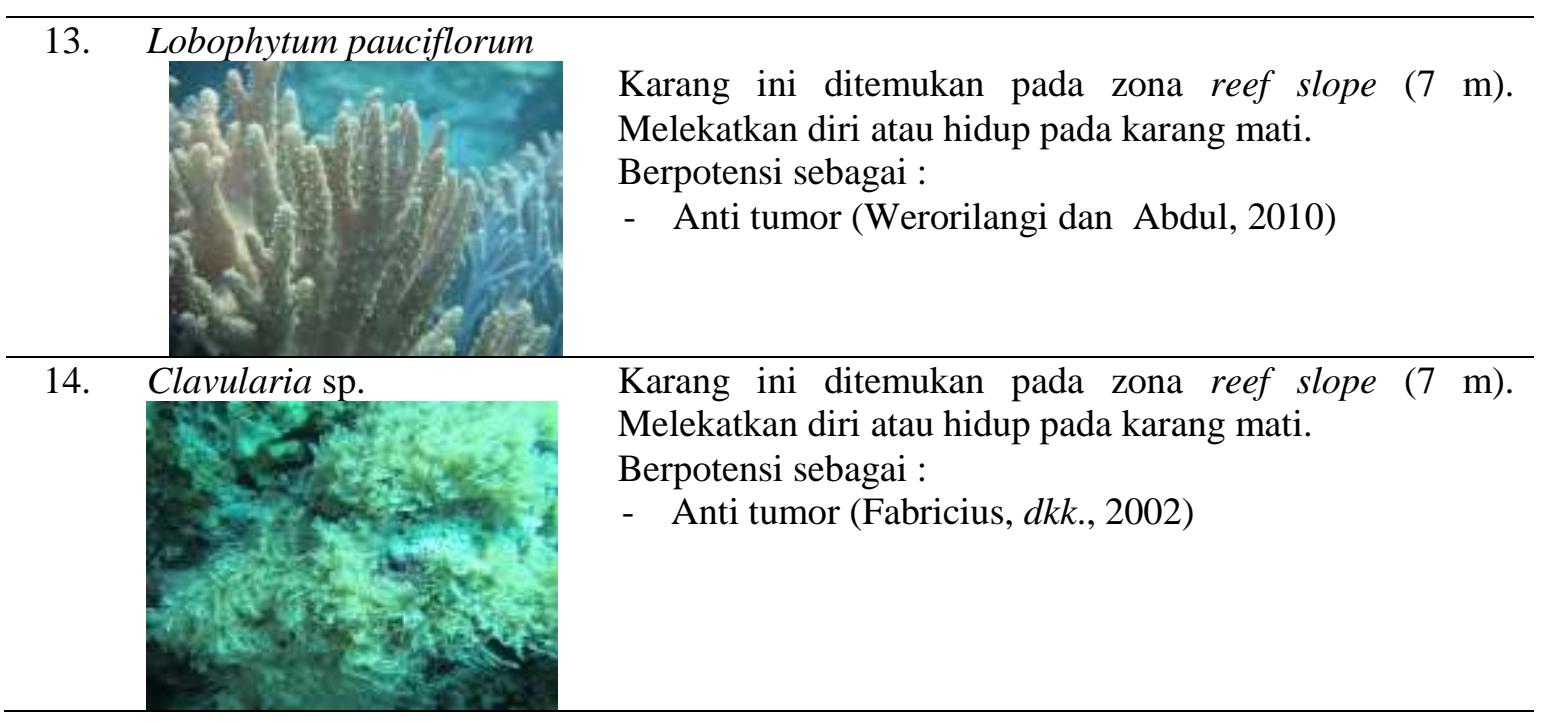

Keberadaan karang lunak jenis bambu laut (I. hippuris) ditemukan melimpah di Perairan Desa Buton dimana nilai kepadatan koloni bambu laut sebesar 0,125 ind. $/ \mathrm{m}^{2}$. Karang lunak jenis ini memiliki nilai ekonomis yang sangat tinggi. Seperti yang di sebutkan Bahri $d k k$, (2016) bahwa, I. hippuris berpotensi sebagai bahan baku farmasi dan sebagai bahan campuran pembuatan keramik porselin. keberadan bambu laut untuk di Perairan Sulawesi sudah berkurang disebabkan para nelayan sering mengambil dan memanfaatkan karang ini untuk di perdagangkan. Karang lunak ini banyak di ekspor dengan tujuan, seperti; Eropa, Amerika dan sebagian Asia terutama ke Cina. Masyarakat di Desa Buton dulunya sering mengambil karang ini untuk di perdagankan, namun adanya peraturan larangan pengambilan karang lunak jenis $I$. hippuris dari pemerintah maka masyarakat di Desa Buton berhenti mengambil karang lunak tersebut. Dalam bidang farmasi karang lunak jenis I. hippuris digunakan sebagai obat anti virus. Manuputty (2008) menyatakan bahwa, jenis oktokoral I. hippuris telah diisolasi senyawa bioaktifnya. Hasil dari penelitiannya itu di dapatkan senyawa Hippuristanol, dimanya senyawa ini dapat memperlambat dan mencegah perkembangbiakan virus dan sel kanker.

Selanjutnya, karang lunak jenis gorgonian sp. berpotensi sebagai karang hias aquarium. Jenis karang ini di temukan di kedalaman $7 \mathrm{~m}$ yaitu di daerah reef slop di celah batu. Populasi karang lunak gorgonian sp. di Perairan Desa Buton sangat sedikit dimana berdasarkan hasil penelitian yang didapatkan nilai kepadatannya sebesar 0,008 ind. $/ \mathrm{m}^{2}$. Manuputty, (2002) menyatakan bahwa, jenis gorgonian sp. umumnya melimpah di tempat yang arusnya deras dan terlindung dari hempasan ombak. Misalnya, di tempat yang terbuka ke arah laut lepas, pada rataan terumbu dengan parit-parit yang tegak lurus garis pantai, dan di celah yang sempit.

Untuk karang lunak jenis xenia sp., memiliki potensi sangat tinggi dimana karang lunak xenia sp. diduga bermanfaat sebagai anti tumor dan anti bakteri. Hasil penelitian Novillia $d k k .$, (2015) ekstrak Xenia sp., fraksi heksan, fraksi kloroform dan fraksi metanol efektif menghambat bakteri Staphylococcus aureus dan bakteri Escherichia coli. Ekstrak dan fraksi ini dikategorikan kuat berdasarkan kriteria Davis dan Stout. Selain itu bentuknya yang cantik dan unik sehingga dapat dijadikan sebagai karang hias di aquarium. Karang lunak ini ditemukan di kedalaman $7 \mathrm{~m}$. Soedharma $d k k$., (2005) menyatakan semakin jauh tempat hidup karang lunak dari daratan utama maka semakin tinggi kandungan bioaktifnya. Berdasarkan hasil penelitian populasi karang lunak xenia sp. yang di temukan di Perairan Desa Buton adalah sangat sedikit jumlahnya, dimana hanya terdapat 3 individu karang lunak. Hal ini disebabkan karang lunak xenia sp. sangat sensitif terhadap perubahan parameter kimia fisika oseanografi perairan, terutama kecerahan. Nilai kecerahan yang ditemukan di tempat penelitian, yaitu $100 \%$. Fikri $d k k$., (2013) menyatakan tingkat kecerahan yang tinggi mempengaruhi pertumbuhan karang lunak karena larva karang lunak dapat menempel dan hidup pada substrat dengan tingkat kecerahan yang rendah. 


\section{Kesimpulan}

Berdasarkan hasil penelitian yang telah dilakukan di Perairan Desa Buton dapat disimpulkan sebagai berikut:

1. Keanekaragaman karang lunak di Perairan Desa Buton terdapat 6 famili, $\quad 10$ genera, 14 jenis, dan 192 individu. Genera yang mendominasi adalah jenis Sarcophyton, Sinularia, Isis, dan Klyxum.

2. Kepadatan karang lunak tertinggi terdapat pada stasiun I dan kepadatan terendah terdapat pada stasiun III, sedangkan berdasarkan zonasi kepadatan tertinggi terdapat di daerah reef slope.

3. Semua karang lunak yang ditemukan di lokasi penelitian berpotensi sebagai anti tumor, anti bakteri, anti kanker, anti jamur, anti oksidan dan berpotensi sebagai karang hias aquarium.

\section{Daftar Pustaka}

Apri, R., Zamani, N. P., dan Efendi, H. 2017. Eksplorasi Karang Lunak Sebagai Antioksidan di Pulau Pongok, Bangka Selatan. Jurnal Teknologi Perikanan dan Kelautan. Vol 2 (2) Hal : 211-217.

Arafat, D. 2009. Pertumbuhan Karang Lunak (Octocorallia:

Alcyonacea)

Lobophytum stricum, Stricum, Sinularia dura dan Perkembangan Gonad Sinularia dura Hasil Fragmentasi Buatan di Pulau Pramuka, Kepulauan Seribu, Jakarta. Institut Pertanian Bogor.

Bahri, S., L., Suraji, Mudatstsir, Rian, P., S., Yudha, M., Prabowo, Marina, M., Nina, T., Syifa, A., Ahmad, S., Erina, N dan Begner S. 2016. Pedoman Rehabilitasi Bambu Laut (isis hippuris) Dengan Metode Transplantasi. Direktorat Konservasi dan Keanekaragaman Hayati Laut.

Dietriech, G. Bengen, Rozirwan, Neviaty, P. Z., Hefni, E dan Chaidir. 2014. Skrining Potensi Senyawa Bioaktif Sebagai Anti Bakteri pada Karang Lunak Dari Perairan Pulau Pongok Bangka Selatan dan Pulau Tegal Telk Lampung. Jurnal Ilmu dan Teknologi Kelautan Tropis. Vol 6. (2). Hal : 283295.

Fabricius K dan G De'ath. 2000. Soft Coral Atlas of the Great Barrier Reef, Australian Institute of Marine Science, http:www.aims.gov.au/softcoral, atlas. $57 \mathrm{pp}$.

Fabricius, K. And P. Aldeslade. 2001. Soft Coral and Sea fans A Comprehensive Guide to the Tropical Shallow Water Genera of the Central-West Pasific, the Indian Ocean and the Red Sea. Australia Institute Of Marine Science. Townsville.

Fabricius, K.E., C. Bastidas, J.A.H. Benzie. 2002. Genetic Differentiation Among Populations Of The Brooding Soft Coral Clavularia Koellikeri on The Great Barier Reef. 21 : 233-241.

Fikri, E., A. Hartoni dan Liliek, L. 2013. Kondisi Tutupan Karang Keras dan Karang Lunak di Pulau Pramuka Kabupaten Administratif Kepulauan Seribu DKI Jakarata. Maspari Jurnal, 5(2), 111-118.

Hanum, L. Dan Aditya, K., K. 2013. Bahan Alam Laut: Senyawa Bioaktif dan Aktivitas Farmakologis Untuk Antimalaria. Vol. XXXVIII. No. 2. Hal: 11-25.

Haya L. O. M. Y and Fuji, M. 2019. Assessing Economic Values Of Coral Reefs In the Pangkajene and Kepulauan Regency, Spermonde. Jurnal Of Coastal Conservasion. Vol (23): 699711.

Iswani, S. Dudi, T. Hedi, I., J. 2014. Identifikasi Senyawa Sitotoksik Karang Lunak Sarcophyton sp. Dari Perairan Pulau Panggang Taman Nasional Kepulauan Seribu. Vol.12 No.2 Hal: 238-243

Juliani, G.,L., Defny, S.,W., Henki, R. 2017. Aktivitas Antibakteri Ekstrak Karang Lunak Klyxum Sp. Yang Diperoleh Dari Teluk Manado. Vol. 6 No. 3. Hal: 46-56

Krebs,C.J. $1999 . \quad$ Ecological Methodology.Harper Collins Publishers. Columbia

Manuputty A.E.W. 2008. Isis Hippuris LINNAEUS 1758 : Oktokoral Penghasil Anti Virus . Vol. XXXIII. No. 1. Hal: 19-24

Manuputty,A.E.W. 2002. (soft coral) Perairan Indonesia. LIPI, Jakarta.

Moelyono, MW. 2016. Farmasi Bahari. Yoogyakarta: Deepublish. 91 hal. 
Munasik. 2009. Konservasi Terumbu Karang. Badan penerbit Universitas Diponegoro Semarang. 56 hal

Nababan, S., M., P., Ruswahyuni, dan Suryanti. 2015. Penutupan Karang Lunak (Soft coral) pada Daerah Rataan dan Daerah Tubir di Pulau Cemara Kecil Kepulauan Karimun Jawa. Vol. 4 No. 3 Hal: 164-169.

Novilia, M., N., K. Defny, S., W dan Adeanne, C., W. 2015. Aktivitas Antibakteri Ekstrak Karang Lunak Xenia sp. Yang Di peroleh Teluk Manado. Vol. 4 No. 3. Hal: 1302-2493.

Putri, R., R., Rozirwan, Fitri, A.2019. Isolasi dan Identifikasi Jamur Simbion pada Karang Lunak Sinularia polydactyla di Perairan Pulau Tegal Dengan Menggunakan Media Yang Berbeda. Jurnal Penelitian SAINS. Vol. 21 (1). Hal : 9-20

Radhika P. 2006. Chemical Constituens and Biological Activities Of The Soft Coral Of Genus Cladlella: A Review, Biochemical Systematich and Ecological, 34: 781-789

Rozirwan,D.G. Bengen, C. Chaidir, N. P. Zamani, and H. Effendi. 2015. "Bacterial symbiont bioactive compound of soft coral Sinularia flexibilis and S. polydactyla," Jurnal Ilmu dan Teknologi Kelautan Tropis, vol. 7 , no. 2

Soedharma, D., Mujizat, K dan Abdul, H. 2005. Kajian Potensi Karang Lunak (Octorallia: Alcyonacea) di Perairan Kepulauan Seribu, DKI Jakarta. Jurnal Ilmu-ilmu Perairan dan Perikanan Ind onesia. Jilid 12. No 2: 121-128.

Sugiyanto, G. 2004. Pertumbuhan dan Kelangsungan Hidup Karang (Caulastrea furcata) Dengan Fragmentasi Buatan di Perairan Pulai Pari Kepulauan Seribu. [Skripsi]. Program Studi Manajemen Sumber Daya Perairan, Fakultas Perikanan Dan Kelautan. Institut Pertanian Bogor, Bogor.

Supriharyono, 2007. Konserfasi Ekosistem Sumber Daya Hayati, Penerbit Pustaka Pelajar, Yogyakarta.

Susana, T. 2005. Kualitas Zat Hara Perairan Teluk Lada, Banten. Oseanologi dan Limnologi di Indonesia: 59-67.
Tinambunan, H. Melki dan Isna. 2012. Efektifitas Ekstrak Bakteri yang Berasosiasi dengan Spons dan Karang Lunak sebagai Antibakteri dari Perairan Pulau Tegal Lampung. Maspari Journal, Vol. 4 (2), 225-230

Werorilangi, S. dan Abdul, H. 2010. Uji Sitotoksisitas Ekstrak (Crude Extract) Karang Lunak (Octocorallia: alcyonacea) Dari Kepulauan Spermonde Kota Makassar. Fakultas Ilmu Kelautan dan Perikanan. Unhas.

Wikanta, T., Yustia A., Z., Dian, R dan M. Nursid. 2006. Uji Aktivitas Sitotoksik Ekstrak Karang Lunak Sarcophyton glaucum (Quoy \& Gaimard) Terhadap Sel Lestari Tumor Hela. Balai Besar Riset Pengolahan Produk dan Bioteknologi Kelautan dan Perikanan, Jakarata.

Yehuda, B., Ming-shiou, J., Shimrit P., F. Adnd Chang, F., D. 2004. Soft Corals (Octocorallia: Alcyonacea) from Southern Taiwan. II. Species Diversity and Distributional Patterns. Zoological Studies 43(3): 548-560. 